\section{Radiocarbon evidence for deglaciation in north-western Himalaya, India}

SINCE the publication of the first post-glacial pollen diagram from Toshmaidan $\left(74^{\circ} 31^{\prime} \mathrm{E}, 33^{\circ} 56^{\prime} \mathrm{N}, \sim 3,120 \mathrm{~m}\right.$ oD) in the Kashmir Valley by one of the authors ${ }^{t}$, the age of the pollen sequence has been a bone of contention ${ }^{2-4}$. The organic deposits overlie a sequence of bluish-grey buttery clay and crushed rock, and were suggested ' ${ }^{\prime}$ to date from the last deglaciation. The pollen sequence was divided into eight stages, and showed a cold-warm-cold climatic sequence, which was similar to previous findings on postglacial climate ${ }^{5}$. Here we present radiocarbon dates on these deposits, and these confirm our previous work.

In early June 1973, an expedition to Kashmir was organised to obtain radiocarbon dates of the inorganicorganic interface, as well as the sedimentary sequence in the mire, at Toshmaidan, and a position stratigraphically close to the original point was selected for collecting samples. The samples dated were subjected to pollen analysis for correlation with the original pollen diagram from the site.

The results of the radiometric dating are shown in Table 1. All but one sample were dated at between $\sim 9,500$ 15,000 b.p., showing that the sedimentation of the organic deposit at Toshmaidan started long before the Neolithic period. The samples which were pollen analysed showed that all samples predating 9,500 b.p. belonged to the time of the first four pollen stages $(a-d)$ (Table 1). The next sample above, however, correlated with the seventh stage $(g)$ of the pollen sequence, and gave a date of 2,790士 160 b.p. As none of the samples showed any similarities with stages $e$ and $f$ it was suggested that there was an erosional break between samples PRL-2(B) $(2,790 \pm$ 160 b.p.) and PRL-3 (9,650 \pm 245 b.p.) which correlated with stages $g$ and $d$ respectively. The gap of nearly $7,000 \mathrm{yr}$ between the radiocarbon dates from the above two samples (Table 1) confirmed the presence of the break in sequence. Because of this disconformity in the sequence it is not possible to calculate the rates of sedimentation in the whole sedimentary profile. This also means that pollen stages $e$ and $f$ in Singh's pollen diagram cannot yet be dated accurately. Nevertheless the dates for these stages cannot be outside the range set by PRL-2(B) $(2,790 \pm 160$ b.p.) and PRL-3 $(9,650 \pm 245$ b.p.), and therefore the stages could still represent broadly the mid-postglacial time to which they had been assigned in ref. 1. Similarly stage $h$, the topmost stage, can now be considered to postdate $2,790 \pm$ 160 b.p. Radiocarbon dates from samples comparable with stages $a-c$ fall between $\sim 14,000$ and 15,000 b.p. and with stage $d$ between 9,500 and 11,000 b.p.
Terminal dates for the pollen stages all remain to be calibrated but it may not be possible to do so accurately without a detailed pollen analysis and fresh radiocarbon dating from the site.

The most significant point to emerge from the present study has been the evidence of deglaciation at Toshmaidan which is shown to have been in progress at $\sim 3,120 \mathrm{~m}$ oD in Kashmir, $\sim 14,000-15,000 \mathrm{yr}$ b p. This date, from the contact between inorganic and organic sediments, is in agreement with the dates generally associated with deglaciation following the last glacial period in several parts of the world ${ }^{6}$. The regional significance of the date for deglaciation from Toshmaidan will become clear as more dates become available from other parts of the Himalayan region. In the global context, the date of deglaciation from Kashmir broadly falls in line with dates obtained from similar elevations in New Guinea ${ }^{7}$ and Ruwenzori, Uganda ${ }^{8}$ in the tropics. There are, however, no available sites providing information on age of deglaciation situated at similar latitude and altitude as Toshmaidan, and, as a result, exact parallels have not yet been found.

Research School of Pacific Studies,

GurdiP SINGH

Australian National University,

Box 4 P.O. Canberra, ACT, Australia

\section{P. Agrawal}

Physical Research Laboratory,

Ahmedabad, India

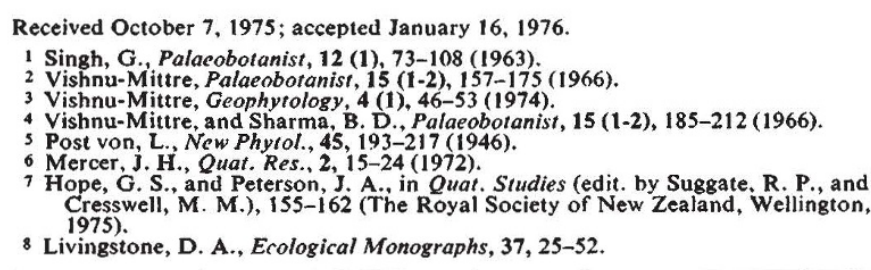

\section{Eastern Greenland basalts} and their supposed plume origin

IT has been suggested ${ }^{1,2}$ that the eastern Greenland flood basalts had their origin in plume activity centred about a triple junction of which Kangerdlugssuaq (Fig. 1) is the failed arm. The suggestion is reviewed here in light of the petrological characteristics and spatial distribution of the basalts.

The main outcrop of lavas is on the Blossville coast in the $450 \mathrm{~km}$ between Kangerdlugssuaq and Scoresby Sund, though scattered, less well known outcrops are found along the $800 \mathrm{~km}$ of coast between Kialineq and Shannon Isle. The lavas were extruded during an early stage of the opening of the North Atlantic from sources on the seaward side of the present outcrops. They thin inland from the coast, where estimates ${ }^{3}$

\begin{tabular}{|c|c|c|c|c|c|c|}
\hline $\begin{array}{c}\text { PRL } \\
\text { number }\end{array}$ & $\begin{array}{c}\text { Serial } \\
\text { number }\end{array}$ & Depth $(\mathrm{cm})$ & Material & $\begin{array}{l}\text { Sieve fraction } \\
(\mu \mathrm{m})\end{array}$ & $\begin{array}{l}\text { Pollen stage } \\
\text { (ref. 1) }\end{array}$ & $\begin{array}{c}\text { Radiocarbon date (yr b.p.) } \\
(\lambda \text { taken as } 5,568 \text { yr })\end{array}$ \\
\hline $\begin{array}{l}2(B) \\
3 \\
4(B)\end{array}$ & III & $\begin{array}{l}15-35 \\
50-70 \\
75-90\end{array}$ & $\begin{array}{l}\text { Peat } \\
\text { Peat } \\
\text { Peat }\end{array}$ & $\begin{array}{l}<420 \\
<420 \\
<420\end{array}$ & $\begin{array}{l}g \\
d \\
d\end{array}$ & $\begin{array}{r}2,790 \pm 160 \\
9,650 \pm 245 \\
10,005 \pm 340 \\
-380\end{array}$ \\
\hline 5 & V & $125-140$ & Peat & $<420$ & $d$ & $\begin{array}{r}11,360_{-}^{+} 585 \\
-600\end{array}$ \\
\hline 7 & VII & $205-220$ & $\begin{array}{c}\text { Fine } \\
\text { organic mud }\end{array}$ & - & $c$ & $13,980+520$ \\
\hline 9 & IX & $280-295$ & $\begin{array}{l}\text { Clay } \\
\text { mud }\end{array}$ & - & $c$ & $15,250+760$ \\
\hline 10 & $\mathrm{X}$ & $317-327$ & $\begin{array}{l}\text { Clay } \\
\text { mud }\end{array}$ & - & $a-b$ & $\begin{array}{r}14,760+1015 \\
-925\end{array}$ \\
\hline 12 & XII & $337-350$ & $\begin{array}{l}\text { Blue-grey } \\
\text { lacustrine clay }\end{array}$ & - & $a-b$ & $\begin{array}{r}13,850_{-}^{+} 900 \\
785\end{array}$ \\
\hline
\end{tabular}

